\title{
Biomonitoring of Mucheke and Shagashe Rivers in Masvingo, Zimbabwe Using Macro-Invertebrates as Indicators of Water Quality
}

\author{
David Chikodzi, Munamato Mabhegedhe, Tatenda Kudakwashe Tunha \\ Gary Magadzire School of Agriculture and Natural Science, Great Zimbabwe University, Masvingo, Zimbabwe \\ Email: mmabhegedhe@gzu.ac.zw
}

How to cite this paper: Chikodzi, D., Mabhegedhe, M. and Tunha, T.K. (2017) Biomonitoring of Mucheke and Shagashe Rivers in Masvingo, Zimbabwe Using Macro-Invertebrates as Indicators of Water Quality. Journal of Geoscience and Environment Protection, 5, 221-237.

https://doi.org/10.4236/gep.2017.59016

Received: July 31, 2017

Accepted: September 23, 2017

Published: September 26, 2017

Copyright $\odot 2017$ by authors and Scientific Research Publishing Inc. This work is licensed under the Creative Commons Attribution International License (CC BY 4.0).

http://creativecommons.org/licenses/by/4.0/

\begin{abstract}
The traditional way of assessing water quality of water bodies is through measurement of biological, physical and chemical parameters. However, such assessments only reflect the concentration of pollutants at the time of sampling not periodic pollution events. The goal of the study was to evaluate the river health using the macro-invertebrates that are found within the Mucheke and Shagashe rivers of Masvingo City as water quality monitors. The South African Scoring System (SASS 5) was used to score using the sensitivity of macro-invertebrates to levels of pollution in the two river systems. The data collection process was carried in April 2017 at four sampling sites using the kick sampling method and results validated by testing the physical, chemical and biological characteristics of the water and comparing them with the macro-invertebrates score. Results showed that the mean sensitivity score of macro-invertebrates showed variations depending on the selected site. Sample sites $\mathrm{B} 2$ and $\mathrm{A} 2$ downstream of the two river systems show high levels pollution tolerant macro-invertebrates as compared to sites A1 and B1 that are on the upper course and have more of pollution sensitive macro-invertebrates. On validation, to a large extent the levels of pollution indicated by macro-invertebrates were found to be congruent to the levels of pollution indicated by the physical, chemical and biological parameters. The research concludes that the presence of specific types of macro-invertebrates can be used to assess the levels of pollution in Mucheke and Shagashe rivers of Masvingo City.
\end{abstract}

\section{Keywords}

Macro-Invertebrates, Water Quality, SASS 5, Mucheke River, 
Shagashe River, Masvingo

\section{Introduction}

Rivers are fast becoming one of the most endangered precious natural resources on earth [1]. The sustainable existence of these freshwater ecosystems continues to be threatened by different anthropogenic activities like agriculture, industrialization and urban development, all of which have the potential to cause deterioration in river water quality [2]. The discharge of wastewaters from industrial, domestic and agricultural sources into river systems introduce different pollutants, which present various detrimental effects, particularly if the physical or chemical properties of the discharges differ from that of the natural river system [3]. While discharges influence the quantity and quality of the water, it can also impact on the ecological integrity and biodiversity of the system [4]. Even though many different organisms contribute to the biodiversity of river water ecosystems, aquatic macro-invertebrates are among the most ubiquitous and diverse group of organisms in these systems because they play a central ecological role in nutrient cycling in these ecosystems [5] [6]. It is on this basis that macro-invertebrates find wide application as ideal organisms in freshwater biomonitoring studies [7].

Macroinvertebrates are simply defined as organisms that lack a spine and are large enough to be seen with the naked eye [8]. Examples of macroinvertebrates include flatworms, crayfish, snails, clams and insects, such as dragonflies [9]. Many aquatic insects live as juveniles, called nymphs or larvae, in the water, and become flying insects as adults [10]. They may be aquatic living organisms and other aquatic invertebrates associated with the substrates of water bodies [11]. Each macroinvertebrate has a unique characteristic. Some are pollution tolerant, some are somewhat tolerant to pollution and others are pollution sensitive [12]. The use of biological organisms to monitor the health of ecosystems is not new with earliest man undoubtedly choosing "healthy" water resources over polluted ones [13]. Benthic aquatic macroinvertebrates are ideal for use in biological monitoring of rivers and is a basic tool that can be used in maintaining the status of the environment, also regarded as the eco status [14].

The traditional means of assessing the impacts of pollution on water bodies are done through the measurement of biological, physical and chemical parameters [15]. However, such measurements only reflect the concentration of pollutants at the time of sampling and measurement, but not episodic or intermittent pollution events [2]. As such, these methods fail to provide enough ecological information because the synergistic effects of pollution on aquatic biotic community may not be fully and easily accessed through chemical and physical measurements [16]. Since physical and chemical assessments cannot on their own form the basis for biodiversity conservation, this leaves biomonitoring of stream conditions as one of the most credible sources of freshwater ecologicals- 
tatus since it provides an integrated and comprehensive assessment of the health of a water body over time [17]. In South Africa for example, the Dragonfly Biotic Index (DBI) has been developed for prioritizing and assessing site conditions for conservation purposes [3]. The shortcomings of physical and chemical water assessments have therefore necessitated the adoption of biological organisms to assess the impacts of anthropogenic activities on water quality in aquatic ecosystems and have given rise to a branch of ecology called biological monitoring (biomonitoring) [18].

Biomonitoring is based on the principle that organisms are the ultimate indicators of the health of the environment they are within [19]. Biomonitoring has the advantage that it can detect cumulative physical, chemical and biological impacts of adverse activities to an aquatic system. Aquatic macro-invertebrates are often preferred for biomonitoring because of the following reasons: they are not very mobile and therefore are representative of the area from which they are collected, they have relatively short life cycles and therefore can reflect environmental changes quickly through changes in their community composition and they respond to pollutants in both water column and sediments [4] [20].

Benthic macro invertebrate fauna are considered to be an excellent water quality indicator because of several reasons [21] [22] [23]. Begum et al. (2009) noted that benthic macro invertebrates often respond to heavy metal contamination and different pollution in different ways, with the quantity and type of the heavy metal in water, sediment, or food determining the degree of pollution [24]. Apart from the fact that benthic macro invertebrates live in intimate contact with the sediments, they are also widespread and often the dominant component of the aquatic fauna, they are relatively easy to collect, identify and enumerate unlike plankton and microorganisms [23]. Contrary to fish and other aquatic animal life, benthic macro invertebrates cannot move around as much, so they are less able to escape the effects of sediment and other pollutants that reduce water quality [25]. Since benthic macro invertebrates portrays a wide variation in sensitivity to heavy metal contaminants and all forms of pollution, the presence or absence of sensitive or tolerant taxa within communities make them excellent bio-indicators of heavy metal pollution. For instance, decreased number in mayfly population indicate severe water quality degradation, while caddisflies can tolerate high exposures to heavy metals even when coated in oxides of manganese $(\mathrm{Mn})$ and iron $(\mathrm{Fe})$ precipitate, and calcium $(\mathrm{Ca})$ minerals [26].

Biomonitoring is therefore a product of the assumption that the response or "health" of biota is a reflection of the "health" of the environment in which they live [27]. It uses resident biota such plants, animals and microorganisms to evaluate effects caused by anthropogenic stress on aquatic ecosystems [28]. Stressed water bodies are often dominated by tolerant organisms with corresponding reduction in the number of sensitive ones [29]. Biomonitoring uses the health or responses of biological organisms to depict changes in the environment that 
could provide indications of environmental stress and hence the need for remedial actions in stressed environment [16].

\subsection{Problem Statement}

Provision of access to clean and safe water is one of the major challenges in developing countries [30]. There is severe pressure on the quantity and quality of freshwater resources in Zimbabwe due to organic and inorganic pollution [29]. The increasing rate of water pollution especially in urban areas is a result of population growth, industrialization, and greater demand for irrigation and livestock production [3]. Assessment of water quality in aquatic systems of Zimbabwe tends to be skewed towards the analysis of physical and chemical properties, thus neglecting the use of biological monitoring tools [31] that are equally important. Physio-chemical analyses provide, at best, a fragmented overview of the state of the water aquatic systems [32]. In contrast, biological monitoring, premised on the fact that living organisms are the ultimate indicators of environmental quality or ecosystem ecological integrity, gives a time-integrated indication of the water quality components because it reflects an overall picture and not only the conditions that were present at the time of sampling and analysis [9]. The unique composite picture of ecosystem conditions provided by biological monitoring can only be replicated by intensive and expensive chemical monitoring studies [31]. Biological monitoring can therefore be recognized as one of the most valuable tools available to ecologists [26]. However, although macro invertebrates are widely recognized as a biomonitoring tool, their application to river health assessments in Zimbabwe is of low precedence hence the need for studies, which equip people with the knowledge to improve our understanding of biological monitoring for the benefit of the communities and various organizations [18].

\subsection{Objectives}

The study aims at assessing the water quality of the Mucheke and Shagashe rivers of Masvingo, Zimbabwe using observed macroinvertebrates as indicators of pollution levels. The research question that the paper seeks to answer is if presence or absence of macroinvertebrates can be used to indicate the water quality of Mucheke and Shagasherivers?

\subsection{Justification}

Water is very important life supporting material and required by all biotic communities [2]. We depend on water for domestic needs, irrigation, sanitation and disposal of wastes. Despite its importance, water is one of the most poorly managed resource [24]. Monitoring and managing a contaminated water system requires knowledge of possible pollutants and their mode of entering into the system [33]. Biological monitoring of rivers although not being effectively implemented in African countries it is regarded as the easiest and cheapest way of 
rapid assessment of water quality [34] that must be adopted and used.

\section{Materials and Methods}

\subsection{Study Area}

The study mainly focuses on two river systems that are: Shagashe and Mucheke rivers. These two rivers pass though Masvingo city and are within Mutirikwi sub-catchment, which is situated in a drought-prone area south-eastern part of Zimbabwe with average rainfall of $600 \mathrm{~mm} /$ year. About $90 \%$ of the precipitation occurs during the period of mid-November to early April [35]. The winter season is from April to August, and the hottest and driest period is from September to mid-November. A large part of the Mutirikwi sub-catchment is within Zimbabwe's natural agro-ecological regions 4 and 5 typified by late onset of rains, early cessation coupled with mid-season dry spells. Masvingo city located in a semi-arid region of Zimbabwe has witnessed a rapid population growth and this has exacerbated water scarcity due to increase in demand. The population of the City has increased from 69,490 in 2002 to 87,886 in 2012 [36]. The Masvingo municipal water supply systems are already struggling to meet adequate water demands of its residents. Due to climate change and variability and increasing pollution of the water sources, these challenges may intensify. Masvingo city has a water supply and water demand ratio of 2.3:4.8, a level so low that the local residence has been forced to endure severe water cuts by the City Council [37]. This gives a compelling reason to improve the monitoring of the quality of the limited water resources available in a manner that is also cost effective hence the need for this study.

\subsection{Sample Sites}

Four (4) sampling sites were selected from the two rivers (Shagashe and $\mathrm{Mu}$ cheke). On each river, one sample was taken on the upper course and another sample taken downstream. Figure 1 shows the sample sites used in the study. These sites include site A1 which is located near Masvingo-Bulawayo road and site A2 which is found near theMasvingo-Beitbridgealong road just outside the central business district of Masvingo City. Both sites A1 and A2 are found along Muchekeriver. Site B1 is located is located upstream of Shagashe river near the Caravan park next to the Masvingo-Mutare road and site B2 is found near Masvingo Teachers' College downstream of Shagashe river.

\subsection{Sampling Methods}

Stratified random sampling was used to select sites for data collection. The two river systems were first divided into upper and lower sections. The upper sections were before the both rivers flow through the City of Masvingo and the lower sections were demarcated downstream of the City. On each section of the strata, samples were collected at random to make sure that all the sections within the two river systems had an equal chance of being sampled. A total of four 


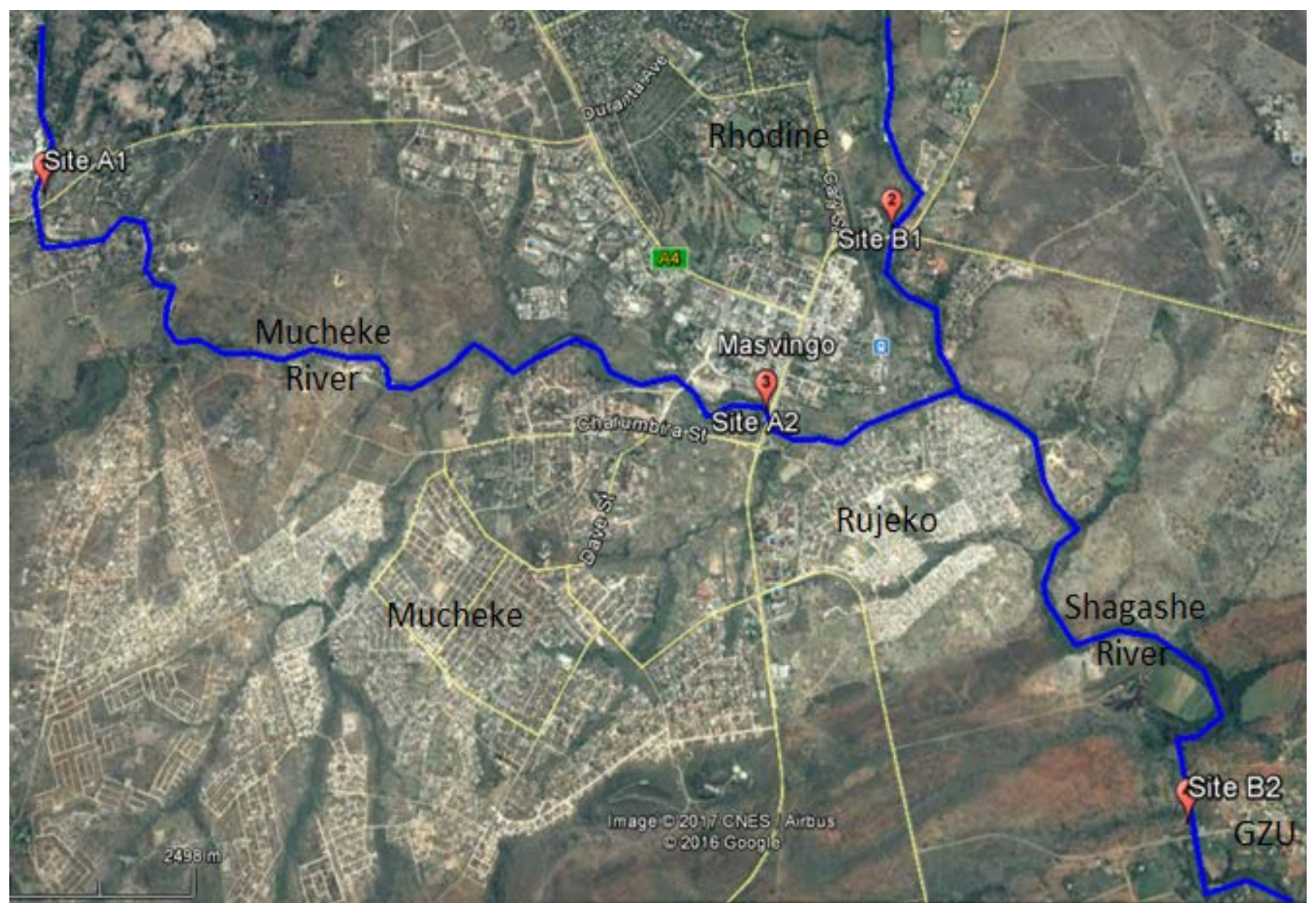

Figure 1. Study Area-Shagashe and Mucheke Rivers, Masvingo.

sampling points were then selected two from each on the upper stream and downstream of both rivers.

Kick sampling was then employed at each selected site for macroinvertebrates determination. This is a widely used method to sample benthic invertebrates in a stream, river, lake or pond since benthic invertebrates dwell at the bottom of a given body of water [38]. It involves kicking the substrate for a given standardized time $(3 \times 30$ second samples), whist holding a mesh net in the direction of flow, allowing the invertebrates to be disturbed and collected in the net [28]. The invertebrates collected were later identified by visual observation using SASS5 references. Kick sampling as a standardized method of measuring benthic invertebrates in a body of water was originally devised by the Centre for Ecology and Hydrology in the UK and later adopted by the European Union Water Framework Directive. It is therefore a tried and tested method and was preferred for use because it is a cheap and cost-effective way to sample benthic invertebrates in water bodies. It is also a straightforward method that can easily be replicated in the field [39]. Macroinvertebrates were sampled by kicking the sediment, scraping the rocks and pebbles with feet, displacing macro-invertebrates whilst continuously sweeping the net (mesh size $500 \mu \mathrm{m}$ ) in scooping motion at the chosen sampling sites. Samples were collected from stagnant, fast and slow 
flowing water and combined into a single stones habitat sample.

Aseptic techniques were used for the collection of water samples for microbiological, physical and chemical parameters testing to maintain the microbiological integrity of the collected water samples. The sampling was done as quickly as possible to reduce incidences that could lead to cross-contamination. Three different water samples were taken from each selected site by manually dipping sterile, previously autoclaved, $500 \mathrm{ml}$ sampling bottles away from the direction of the river flow until they were three quarters full. These were later combined to form one $1000 \mathrm{ml}$ composite sample. Collected water samples were immediately put in cooler boxes containing ice during sampling and later stored at $4^{\circ} \mathrm{C}$ in the laboratory refrigerator prior to microbiological parameters testing.

\subsection{Analytical Methods}

Measurement of $\mathrm{pH}$, conductivity and dissolved oxygen was done using a portable multi-parameter water meter. Total coliforms determination was done to indicate the microbiological quality of river, using the standard multiple tube fermentation technique. Detection was done by inoculation of water samples into tubes of lactose broth to determine the most probable number (MPN) of coliform bacilli. Water samples of $1 \mathrm{ml}$ and $0.1 \mathrm{ml}$ were inoculated into test-tubes with $9 \mathrm{ml}$ of lactose broth and incubated at $35^{\circ} \mathrm{C} \pm 0.5^{\circ} \mathrm{C}$ for 24 hours. Gas formation after incubation period indicated a presumptive positive test for coliforms and absence of gas a negative test. Tubes with presumptive positive coliform results were then inoculated oneosine-methylene-blue agar; and one colony picked off into Brilliant Green Bile broth. The picked colonies were studied microscopically to confirm the morphological and staining properties of coliform bacilli.

\subsection{The South African Scoring System (SASS)}

The South African Scoring System (SASS) is a biotic index based on the presence of selected families of aquatic macro invertebrates and their perceived sensitivity to water quality changes [29]. SASS is a modification of the Biological Monitoring Working Party (BMWP) Scoring System, and has undergone several improvements resulting in the current South African Scoring System version 5 (SASS5). Under SASS5 macroinvertebrate families are awarded scores based on their perceived sensitivity to pollution in the range of 1 to 15 in increasing order of their sensitivity to water quality changes. Table A1 shows the SASS Version 5 scoring sheet used in the study. SASS5 results are expressed both as an index score and as average score per recorded taxon (ASPT) value [29] [39].

SASS5 was adopted in the study because, it is easy and simple to operate since it does not require sophisticated equipment; the method is cheap and results are easily interpreted and conveyed to water resources managers; the sampling is generally non-destructive except where representative collections are required [40] and it provides an insight into the biological status of rivers in terms of en- 
vironmental water quality [39].

However, because SASS is a rapid bio-assessment method developed for rapid assessment of environmental water quality, it has some limitations. For example, it is a single biotic index and as such, it masks ecological information from all levels of the ecosystem that is, from individual, population and community levels. Several studies indicate that using a multimeric approach (i.e. the use of multiple metrics from different ecosystems levels and functions) rather than a single biotic index would provide more robust ecological information needed for the management of water resources [41]. In addition, because of its rapid assessment nature, taxonomic resolution in SASS is at the family level. Therefore, changes in species composition, abundance and distribution within a family in relation to environmental water quality changes may not be detected. These limitations posed the need for the exploration and possible application of other (new or available) methods that could be used along with SASS in the assessment of the river [42].

\subsection{The Interpretation of the Average Score According to the SASS5}

A total SASS5 score for a particular site was derived from a summation of all family scores of macroinvertebrates at a site. With this, the average score was calculated by getting a quotient between the total SASS5 score and number of families recorded at a site. Score ranges between 1 - 5 means that the macroinvertebrates can live in highly polluted areas and these are not so sensitive to pollution. These only develop where pollution levels are high for example pollution from heavy metals. Scores from 6 - 10 mean that such macroinvertebrates favour where pollution is moderate and can survive under such conditions. Lastly the score ranges from $11-15$ these macroinvertebrates become extinct if they are introduced in highly polluted water and their lives can only be sustained in clean and fresh waters. The scores are indicated below as follows:

- 1 - 5 Highly tolerant to pollution.

- 6 - 10 Moderately tolerant to pollution.

- 11 - 15 Very low tolerance to pollution.

\subsection{Validation of SASS5 Scores}

To validate the results from SASS5 on levels of pollution in the water bodies, samples for the measurement of physical, chemical and microbiological water quality parameters were also taken as described above. The levels of agreement between SASS5 scores on water quality and the results of the coliform bacilli counts, as well as the dissolved oxygen (DO), conductivity (C) and $\mathrm{pH}$ measurements were compared. The coliform scores categories and their respective interpretations are indicated in Table 1.

\section{Results}

Table 2 shows the identified macroinvertebrates on the selected sites (A1, A2, B1 
Table 1. Microbiological quality categories of coliforms according to WHO (2008) guidelines.

\begin{tabular}{cccc}
\hline Category & MPN range & Grade & Usage \\
\hline I & 0 & Excellent & Drinking \\
II & $0-50$ & Good & Bathing/Swimming \\
III & $51-400$ & Fair & Bathing/Swimming \\
IV & $400-1100$ & Poor & Unfit for human use \\
\hline
\end{tabular}

Table 2. UTM Zone 36 South coordinates of sampling sites and identified macroinvertebrate species.

\begin{tabular}{|c|c|c|c|}
\hline Site & $\mathrm{X}$ & $\mathrm{Y}$ & Identified macroinvertebrates species \\
\hline A1 & $267,860.11$ & $7,780,135.49$ & $\begin{array}{l}\text {-Anodonta sp., Caenidae sp., Psephenidae sp., } \\
\text { Leptoceridae sp., Psychomyiidae sp., } \\
\text { Hydroptilidae sp. and Hexatoma sp. }\end{array}$ \\
\hline A2 & $273,211.20$ & $7,778,422.64$ & -Glossiphonidae sp. and Erpobdellidae sp. \\
\hline B1 & $274,187.21$ & $7,779,744.34$ & $\begin{array}{l}\text {-Antocha sp., Leptophlebiidae sp., Perlidae sp., } \\
\text { Siphlonuridae sp., and Arctopsychidae sp., } \\
\text { Hydrophilidae sp., Dytiscidae sp., } \\
\text { Ephemeridae sp., Tipula sp., } \\
\text { and Tabanidae sp. }\end{array}$ \\
\hline B2 & $276,030.01$ & $7,775,585.02$ & $\begin{array}{l}\text { - Chironomidae sp., Ceratopogonidae sp., and } \\
\text { Lymnaeidae sp. }\end{array}$ \\
\hline
\end{tabular}

and B2). The results directly indicate that the pollution levels at site A1 and B1 was moderate as compared to site A2 and B2. This is in agreement with the observations of Tables 3-6.

Tables 3-6 show the macroinvertebrate scores and tested water quality parameters for sites A1, A2, B1 and B2 and their interpretations. Assessment of the physico-chemical and biological water quality characteristics was done through the use of WHO (2008) guidelines, which are considered to be universal and accepted worldwide [43]. As shown in Table 3, at site A1 on Muchekeriver, according to SASS5 benchmark, the measured score indicates moderatepollution on the water quality levels due to the presence of macroinvertebrates that are considered moderately tolerant to pollution. The identified macroinvertebrates included Anodontasp., Caenidae sp., Psephenidae sp., Leptoceridae sp., Psychomyiidae sp., Hydroptilidae sp. and Hexatomasp. that indicate good or moderate water quality (Table 2). The score was also validated by the tested coliforms, $\mathrm{pH}, \mathrm{DO}$ and conductivity parameters that all indicated that the water was within the accepted limits of pollution. These observations resonate well with the situation on the ground, because site A1 is situated upstream where there are less anthropogenic or industrial operations that directly dispose their waste water into the river. The likely source of pollution at this site comes from agricultural run-off from communities living upstream and a quarry stone plant's effluent that can easily flow into the river thus compromising the quality of the river water. 
Table 3. Macroinvertebrate scores and tested water quality for site A1 (Mucheke river upstream).

\begin{tabular}{|c|c|c|c|}
\hline PARAMETER & SASS5 STANDARD & MEASURED & INTERPRETATION \\
\hline MACROINVERTEBRATES & $\begin{array}{l}1 \text { - 5: Pollution tolerant } \\
6-10 \text { : moderate } \\
11-15: \text { little or less } \\
\text { tolerant to pollution }\end{array}$ & 7.1 & Moderately Polluted \\
\hline $\mathrm{PH}$ & $\begin{array}{c}\text { STANDARD (WHO) } \\
6.5-8.5\end{array}$ & 7.88 & Within range \\
\hline $\mathrm{DO}$ & $>6.0$ & 8.65 & Within range \\
\hline CONDUCTIVITY & $<400$ us/m & $0.266 \mathrm{us} / \mathrm{m}$ & Within range \\
\hline COLIFORMS & & $51 \mathrm{mpn} / 100 \mathrm{ml}$ & Fair quality water \\
\hline
\end{tabular}

Table 4. Macroinvertebrate scores and tested water quality for site A2 (Muchekeriver downstream).

\begin{tabular}{|c|c|c|c|}
\hline PARAMETER & SASS5 STANDARD & MEASURED & INTERPRETATION \\
\hline \multirow[t]{2}{*}{ MACROINVERTEBRATES } & $\begin{array}{l}1 \text { - 5: Pollution tolerant } \\
6-10 \text { : moderate } \\
11-15: \text { little or less } \\
\text { tolerant to pollution }\end{array}$ & 3.4 & Polluted \\
\hline & STANDARD (WHO) & & \\
\hline $\mathrm{PH}$ & $6.5-8.5$ & 9.31 & Above accepted range \\
\hline DO & $>6.0$ & 9.7 & Within range \\
\hline CONDUCTIVITY & $<400 \mathrm{us} / \mathrm{m}$ & $93.5 \mathrm{us} / \mathrm{m}$ & Within range \\
\hline COLIFORMS & & $204 \mathrm{mpn} / 100 \mathrm{ml}$ & Fair water quality \\
\hline
\end{tabular}

Table 5. Macroinvertebrate scores and tested water quality for site B1 (Shagasheriver upstream).

\begin{tabular}{cccc}
\hline PARAMETER & SASS5 STANDARD & MEASURED & INTERPRETATION \\
\hline MACROINVERTEBRATES & $\begin{array}{l}\text { 1 - 5: Pollution tolerant } \\
6 \text { - 10: moderate } \\
11-15 \text { : little or less } \\
\text { tolerant to pollution } \\
\text { STANDARD }(\mathrm{WHO})\end{array}$ & 10.5 & Moderately polluted \\
PH & $6.5-8.5$ & 7.61 & \\
DO & $>6.0$ & 7.95 & Within range \\
CONDUCTIVITY & $<400 \mathrm{us} / \mathrm{m}$ & $43.5 \mathrm{us} / \mathrm{m}$ & Within range \\
COLIFORMS & & $25 \mathrm{mpn} / 100 \mathrm{ml}$ & Good water quality \\
\hline
\end{tabular}

Table 4 shows the macroinvertebrate scores and tested water quality for site A2. At this sampling site which is downstream of Muchekeriver, the recorded SASS5 score is 3.4 which indicates that the water is highly polluteddue to the presence of mainly macroinvertebrates that are pollution tolerant. Macroinvertebrates identified at this site include Glossiphonidae sp. and Erpobdellidae sp. 
Table 6. Macroinvertebrate scores and tested water quality for site B2 (Shagasheriver downstream).

\begin{tabular}{cccc}
\hline PARAMETER & \multicolumn{1}{c}{ SASS5 STANDARD } & MEASURED & INTERPRETATION \\
\hline & $\begin{array}{l}\text { 1 - 5: Pollution tolerant } \\
\text { MACROINVERTEBRATES }-10 \text { : moderate } \\
\text { 11 - 15: little/less } \\
\text { tolerant to pollution } \\
\text { STANDARD }(\mathrm{WHO})\end{array}$ & 4.5 & Polluted \\
PH & $6.5-7.5$ & 9.57 & Above accepted range \\
DO & $>6.0$ & 4.8 & Below accepted range \\
CONDUCTIVITY & $<400 \mathrm{us} / \mathrm{m}$ & $132.8 \mathrm{us} / \mathrm{m}$ & Within range \\
COLIFORMS & & $1420 \mathrm{mpn} / 100 \mathrm{ml}$ & Poor water quality \\
\hline
\end{tabular}

(Table 2) that are common indicator species of poor quality water levels. The SASS5 score was also confirmed by the $\mathrm{pH}$ levels of that above the maximum acceptable limit for good quality water. Despite the DO and conductivity being within their accepted ranges, their threshold steeply increased from the previous sampling point, site A1, which is located upstream of the same river. This indicates the effect of anthropogenic pollutants introduced into the river as it flows past Masvingo city's residential and industrial areas, as well as the city's central business district (CBD).

Table 5 shows the macroinvertebrate scores and tested water quality for sampling site B1, which is found upstream of the Shagasheriver. The SASS5 score of 10.5 shows that the water is moderately polluted. This scenario is strongly supported by the coliform bacteria counts that confirm that the water quality is good. The macroinvertebrates found on this site included, Antocha sp., Leptophlebiidae, Perlidae, Siphlonuridae, Hydrophilidae, Dytiscidae, Ephemeridae, Tipula sp., and Tabanidae and Arctopsychidae sp., which indicate good water quality.

Table 6 shows the results from sample site B2, which is downstream of Shagasheriver. The site recoded a SASS5 score of 4.5 which indicates the presence of mainly pollution tolerant macroinvertebrates implying that the water is polluted. The observed macroinvertebrates were Chironomidae sp., Ceratopogonidae sp., and Lymnaeidae sp., all of which survive in polluted waters, thus indicating extremely poor water quality. These dominate in polluted water with high concentration of organic materials and nutrients, but other species cannot survive [44]. ThisSASS5 score was also validated by the $\mathrm{pH}$ and DO values that were both out of the accepted range for good quality water and a very high coliform count that indicated a very poor water quality rating, unfit for human use [43]. To a large extent the levels of pollution on this part of the river can also be confirmed by the high concentration of the water hyacinth plants, which are also a signature mark of the presence of high water nutrient content [41]. The mainreason to justify the high levels of water pollution observed on this site is the presence of city's domestic and industrial wastewater effluent treatment plant upstream that 
discharges its treated effluent into the river. There is high likelihood that the discharged effluent from the treatment plant may be of poor quality due to persistent power-cuts and also due to poorly serviced and dilapidated wastewater treatment infrastructure that is no longer fit for purpose. In addition, most of the waste and pollutants that are discharged from the city of Masvingo eventually end up on this part of the river including all the polluted water from Mucheke river, which joins the Shagasheriver upstream.

\section{Discussion}

Biological monitoring tools for water quality assessment are largely lacking for many developing countries including Zimbabwe, resulting in adoption of tools developed from other countries. In many instances, their applicability to a new environment has not been explicitly evaluated in Zimbabwe, hence the objective of this study. The results obtained generally show that the SASS5 system can be easily adopted and used for the general rapid assessment of water quality of rivers found in Masvingo, which is a semi-arid region in Zimbabwe. This is in agreement to studies done to test the applicability of this system in other streams in Zimbabwe [45]. This also confirmed the occurrence of ubiquitous macroinvertebrate taxa in Zimbabwe sharing similar environmental tolerances with those recorded for South African systems [29] [46].

During the validation of the observed macroinvertebrates results, it was noted that the other water quality parameters such as $\mathrm{pH}, \mathrm{DO}$ and coliform counts were more consistent with the obtained SASS5 scores further confirming the suitability of this system. In their study of the applicability of the SASS5, Bere and Nyakupingidza (2014) applied it to test some urban streams in Zimbabwe [45]. The study assessed the correlation between physical and chemical water quality variables and SASS5 indices. A high degree of agreement between water chemistry parameters and SASS5 metrics was observed, thus indicating the suitability of using SASS scores in detecting water changes in Zimbabwe. Despite the above agreement, the applicability of SASS 5 metrics still needs to be tested in different geographical and climatic regions of the country and any observed disparities among the different regions noted in order to adopt the index for the entire country [45].

Zimbabwe is also not the only country in Africa to test the applicability of the SASS5 scores. Munyika et al. (2014) carried out a study along the Orange River in Namibia aimed at assessing the current water quality and overall health status of the Orange River in Namibia using the South African Scoring System 5 (SASS5) [47]. Gerhardt, (2000) notes that land use activities that have an effect on water quality and river health are believed to increase the pollution of water in most rivers [10]. Namibia most practiced their agriculture along the Orange river and this increased the pollution tolerant macroinvertebrates along the Orange river with other anthropogenic activities including urban development, weir construction and population increase along the river has resulted in proliferation of unplanned settlements with no proper sanitation facilities and in- 
creases in pollution levels along the river [47].

The fact that sampling sites A1 and B1, both located upper stream of the two studied river systems have relatively moderate-good quality water according to SASS5 scores can be explained by the fact that there are less anthropogenic or industrial operations that directly dispose their wastewater effluent into the rivers at these two sites. The SASS5 scores were in agreement with the recorded values for $\mathrm{pH}, \mathrm{DO}$, conductivity and the coliform bacteria. The obtained $\mathrm{pH}$ values gave an indication that the water was not too acidic or too alkaline (basic) and DO values showed an abundance of oxygen in the water that adequately supports the growth and proliferation of most aquatic organisms [43]. The coliform counts indicated good water quality levels fit for bathing or swimming at site Aland within the accepted limit for drinking water at site B1. The likely source of pollution at sites $\mathrm{A} 1$ and $\mathrm{B} 1$ comes from agricultural run-off from communities living upstream. However, because sampling was done in April, at the end of the rain season, it is safe to assume that most agricultural contaminants and runoff were already washed away and no longer in the river system due to the end of the rain-fed farming season and also the high rainfall levels that were received in 2017.

The observed significant deterioration in the river water quality at sample sites A2 and B2 downstream, according to SASS5 scores and validated by high coliform counts and $\mathrm{pH}$ can be explained by the fact that the rivers have both passed through industrial and residential areas where there is thriving anthropogenic activities upstream. In addition, the city's wastewater treatment plant also disposes its treated waste effluent, which has often been regarded as of poor quality, into Shagashe river upstream of site B2, thus likely contributing to the high coliform counts recorded at this site [48]. Furthermore, it has been reported in various studies that there is massivestreambank cultivation within the residential suburbs of Mucheke and Rujeko upstream of sites A2 and B2, as well as reported direct discharge of untreated sewage, industrial effluent, abattoirs wastewater and agricultural effluent into the rivers, thus likely impacting on the quality of the water [48] [49]. The observed results also resonate with the existence of the extensive growth of water hyacinth on site B2, an invasive plant species that commonly grows and colonises polluted water bodies. The existence of this plant is thought to reduce the available oxygen (DO) required for the survival of most aquatic organisms [43].

\section{Conclusion}

The research indicates that macroinvertbrates are indeed good indicators of water pollution, despite not being commonly used in water quality studies as compared to the other microbiological, physical and chemical water quality testing parameters. Therefore, there is need to adopt this biomonitoring method widely in Zimbabwe to complement the other commonly used water quality parameters in order to yield effective results. Going forward, there is a need for continuous 
biomonitoring of various water resources across the country for pollution control and also to establish and optimize Zimbabwean biomonitoring standards of scoring rather than relying on standards adopted from foreign countries.

\section{References}

[1] Dudgeon, D., Arthington, A.H., Gessner, M.O., Kawabata, Z., Knowler, D.J., Leveque, C., Naiman, R.J., Prieur-Richard, A., Soto, D., Stiassny, M.L.J. and Sullivan, C.A. (2006) Freshwater Biodiversity: Importance Threats, Status and Conservation Challenges. Biological Reviews, 81, 163-182. https://doi.org/10.1017/S1464793105006950

[2] Debén, S., Aboal, J.R., Carballeira, A., Cesa, M. and Fernández, J.A. (2017) Monitoring River Water Quality with Transplanted Bryophytes: A Methodological Review. Ecological Indicators, 81, 461-470. https://doi.org/10.1016/j.ecolind.2017.06.014

[3] Simaika, J.P. and Samways, M.J. (2009) An Easy-to-Use Index of Ecological Integrity for Prioritising Freshwater Sites and for Assessing Habitat Quality. Biodiversity and Conservation, 18, 1171-1185. https://doi.org/10.1007/s10531-008-9484-3

[4] Mehari, A.K., Wondie, A., Mingist, M. and Vijverberg, J. (2014) Spatial and Seasonal Variation in the Macro-Invertebrates and Physico-Chemical Parameters of the Enfranz River, Lake Tana Sub-Basin (Ethiopia). Ecohydrology \& Hydrobiology, 14, 304-312. https://doi.org/10.1016/j.ecohyd.2014.07.004

[5] Callisto, M., Moreno, P. and Barbosa, F.A.R. (2001) Habitat Diversity and Benthic Functional Trophic Groups at Serra Do Cipo, Southeast Brazil. Revista Brasileira de Biologia, 61, 259-266. https://doi.org/10.1590/S0034-71082001000200008

[6] Strayer, D.L. (2006) Challenges for Freshwater Invertebrate Conservation. Journal of the North American Benthological Society, 25, 271-287. https://doi.org/10.1899/0887-3593(2006)25[271:CFFIC]2.0.CO;2

[7] Dallas, H.F. and Mosepele, B. (2007) A Preliminary Survey and Analysis of the Spatial Distribution of Aquatic Invertebrates in the Okavango Delta. African Journal of Aquatic Science, 32, 1-11. https://doi.org/10.2989/AJAS.2007.32.1.1.138

[8] Mandaville, S. (2002) Benthic Macroinvertebrates in Freshwater Taxa Tolerance Values, Metrics and Protocols. Project H-1, Soil \& Water Conservation Society of Metro Halifax. http://chebucto.ca/Science/SWCS/SWCS.html

[9] Chakupa, T. (2011) Environmental Management in Chrome Mining along the Great Dyke: A Case of ZIMASCO Operations. Unpublished Thesis, University of Stellenbosch.

[10] Gerhardt, A. (2000) Biomonitoring of Polluted Water. Trans-Tech Publications Ltd., Switzerland:

[11] Heip, C. and Engels, P. (1974) Comparing Species Diversity and Eveness Indices. Journal of the Marine Biological Association, 54, 559-563. https://doi.org/10.1017/S0025315400022748

[12] Merrit, R.W., Cummins, K.W. and Berg, M.B. (2008) An Introduction to Aquatic Insects of North America. 4th Edition, Kendall Hunt Publishers, Dubuque.

[13] Hughes, R.M., Larsan, D.P. and Omernik, J.M. (1986) Regional Reference Sites: A Method for Assessing Stream Pollution. Environmental Management, 10, 629-635. https://doi.org/10.1007/BF01866767

[14] Kleynhans, C.J. and Louw, M.D. (2007) EcoClassification and EcoStatus Determination in RiverEcoClassification: Manual for EcoStatus Determination (Version 2). 
Joint Water Research Commission and Department of Water Affairs and Forestry Report.

[15] Ollis, D.J., Dallas, H.F., Esler, K.J. and Boucher, C. (2006) Bioassessment of the Ecological Integrity of River Ecosystem Using Macroinvertebrates: An Overview with a Focus on South Africa. African Journal of Aquatic Science, 31, 205-227. https://doi.org/10.2989/16085910609503892

[16] Rosenberg, D.M. and Resh, V.H. (1993) Fresh Water Monitoring and Benthic Macroinvertebrates. Chapman and Hall Publishers, New York.

[17] Karr, J.R. and Chu, E.W. (1999) Restoring Life. In: Running Waters, Island Press, Calif, 206.

[18] Utete, B., Mutasa, L., Ndhlovu, N. and Tendaupenyu, I.H. (2013) Impact of Aquaculture on Water Quality of the Lake Kariba. International Journal of Aquaculture, 3, 11-16.

[19] U.S. Environmental Protection Agency (USEPA) (2002) Methods for Measuring the Acute Toxicity of Effluents and Receiving Waters to Freshwater and Marine Organisms. 5th Edition, Washington DC, EPA-821-R-02-012.

[20] Reece, P.F. and Richardson, J.S. (2000) Benthic Macroinvertebrate Assemblages of Coastal and Continental Streams and Large Rivers of Southwestern British Columbia, Canada. Hydrobiologia, 439, 77-89. https://doi.org/10.1023/A:1004105820586

[21] Metcalfe, J. (1989) Biological Water Quality Assessment of Running Waters Based on Macroinvertebrate Communities: History and Present Status in Europe. Environmental Pollution, 60, 101-139. https://doi.org/10.1016/0269-7491(89)90223-6

[22] Cuffney, T.F. and Brighbill, R.A. (2011) User's Manual for the National Water Quality Assessment Program, Invertebrate Data Analysis System (IDAS) Version 5. U.S Ecological Survey Techniques and Methods, 7, 126.

[23] Beasley, G. and Kneale, P.E. (2002) Reviewing the Impact of Metals and PAHs on Macroinvertebrates in Urban Watercourses. Progress in Physical Geography, 26, 236-270. https://doi.org/10.1191/0309133302pp334ra

[24] Begum, A., Ramaiah, M., Khan, H.I. and Veena, K. (2009) Analysis of Heavy Metals Concentration in Soil and Litchens from Various Localities of Hosur Road, Bangalore, India. E-Journal of Chemistry, 6, 13-22. https://doi.org/10.1155/2009/943695

[25] Paul, M.J. and Meyer, E. (2001) Streams in Urban Landscape. Annual Review of Ecology and Systematics, 32, 333-365. https://doi.org/10.1146/annurev.ecolsys.32.081501.114040

[26] Azrina, M.Z., Yap, C.K., Rahin, A., Ismail, A. and Tan, S.G. (2006) Anthropogenic Impacts on the Distribution and Biodiversity of Benthic Macroinvertebrates and Water Quality of the Langat River. Ecotoxicology and Environmental Safety, 64, 337-347. https://doi.org/10.1016/j.ecoenv.2005.04.003

[27] Bonada, N., Prat, N., Resh, V.H. and Statzner, B. (2006b) Devolopments in Aquatic Insect Biomonitoring: A Comparative Analysis of Recent Approaches. Annual Reviews of Entomology, 51, 495-523.

https://doi.org/10.1146/annurev.ento.51.110104.151124

[28] Downes, B.J., Barmuta, L.A., Fairweather, P.G., Faith, D.P., Keough, M.J., Lake, P.S., Mapstone, B.D. and Quinn, G.P. (2002) Monitoring Ecological Impacts. Concepts and Practice in Flowing Waters. Cambridge University Press, Cambridge. https://doi.org/10.1017/CBO9780511542015

[29] Chutter, F. (1993) Relations between Low Flows and River Fauna of the Letaba River. Water Research Commission, 293. 
[30] UNEP (2002) Water Supply and Sanitation Coverage in UNEP Regional Seas, Need for Regional Wastewater Emission Targets? Section I: Regional Presentation of Data. UNEP/GPA, The Hague, The Netherlands.

[31] Mugadza, C.H. (2005) Climate Change and Water Supply Security in Southern Africa. Proceedings of the University Lake Kariba Research Station Seminar Series, Kariba, Bulletin No.2/05.

[32] Ndebele, M. (2009) Primary Production and Other Limnological Aspects of Cleveland Dam, Lakes Reservoirs. Research and Management, 14, 151-161. https://doi.org/10.1111/j.1440-1770.2009.00395.x

[33] Benetti, C.J. and Garrido, J. (2010) The Influence of Stream Habitat and Water Quality on Water Beetles Assemblages in Two Rivers in Northwest Spain. Vie et milieu, 60, 53-63.

[34] Ndebele, M. (2012) Biological Monitoring and Pollution Assessment of the Mukuvisi River, Harare, Zimbabwe, Lakes and Reservoirs. Research and Management, 17, 73-80. https://doi.org/10.1111/j.1440-1770.2012.00497.x

[35] Chikodzi, D. (2013) Spatial Modelling of Malaria Risk Zones Using Environmental, Anthropogenic Variables and Geographical Information Systems Techniques. Journal of Geosciences and Geomatics, 1, 8-14.

[36] ZimStats (2012) Census 2012: Preliminary Report. Government Printer, Harare.

[37] Mapfumo, A. and Madesha, W.M. (2014) Challenges for Urban Water Supply: The case of Masvingo Municipality in Zimbabwe. International Journal of Environmental Research, 5, 1-5.

[38] Elbag, M.A. (2006) Impact of Surrounding Land Uses on Surface Water Quality. Unpublished MSc Thesis, Worcester Polytechnic Institute, Worcester, MA.

[39] Dickens, C.W.S. and Graham, P.M. (2002) South African Scoring System (SASS 5), Rapid Bioassessment Method for Rivers. African Journal of Aquatic Science, 27, 1-10. https://doi.org/10.2989/16085914.2002.9626569

[40] Davies, B. and Day, J. (1998) Vanishing Waters. UCT Press, Cape Town.

[41] Lücke, J.D. and Johnson, R.K. (2009) Detection of Ecological Change in Stream Macroinvertebrate Assemblages Using Single Metric, Multimetric or Multivariate Approaches. Ecological Indicators, 9, 659-669. https://doi.org/10.1016/j.ecolind.2008.08.005

[42] Sánchez-Montoya, M.M., Vidal-Abarca, M.L. and Suarez, M.L. (2010) Comparing the Sensitivity of Diverse Macroinvertebrate Metrics to a Multiple Stressor Gradient in Mediterranean Streams and Its Influence on the Assessment of Ecological Status. Ecological Indicators, 10, 896-904. https://doi.org/10.1016/j.ecolind.2010.01.008

[43] World Health Organization (2008) Guidelines for Drinking Water Quality, Incorporating First and Second Agenda. 3rd Edition, Volume 1, Recommendations, WHO, Geneva.

[44] Arimoro, F.O. and Ikomi, R.B. (2008) Response of Macroinvertebrates to Abattoir Wastes and Other Anthropogenic Activities in a Municipal Stream in the Niger Delta, Nigeria. Environmentalist, 28, 85-98. https://doi.org/10.1007/s10669-007-9033-8

[45] Bere, T. and Nyakupingidza, S. (2014) Use of Biomonitoring Tools beyond Their Country of Origin. Case Study of South African Scoring System (SASS 5). Hydrobiologia, 722, 223-232. https://doi.org/10.1007/s10750-013-1702-7

[46] Dugel, M. (1995) Assessment of Water Quality of the Buyuk Menderes River Using Ordination and Classification of Macroinvertebrates and Environmental Variables. 
Journal of Freshwater Ecology, 19, 605-612. https://doi.org/10.1080/02705060.2004.9664741

[47] Munyika, S., Kongo, V. and Kimwaga, R. (2014) River Health Assessment Using Macroinvertebrates and Water Quality Parameters: A Case of the Orange River in Namibia. Physics and Chemistry of the Earth, 76-78, 140-148. https://doi.org/10.1016/j.pce.2015.01.001

[48] Sharma, P., Sood, A., Sharma, S., Bisht, S., Kumar, V., Pandey, P., Gusain, M.P. and Gusain, O.P. (2010) Bacterial Indicators of Faecal Pollution and Physiochemical Assessment of Important North Indian Lakes. RMZ-Materials and Geoenvironment, 57, 25-40.

[49] Sadat-Noori, S.A., Ebrahimi, M., Khazaei, J. and Khalaj, H. (2011) Predicting Yield of Wheat Genotypes at Different Salinity by Artificial Neural Network. African Journal of Agricultural Research, 6, 2660-2675.

\section{Appendix}

Table A1. The SASS Version 5 scoring sheet.

\begin{tabular}{|c|c|c|c|c|c|c|c|c|c|c|c|c|c|c|c|c|}
\hline SASSVersion5ScoreSheet & Taxon & & S Veg & GSM & TOT & Taxon & & $\mathbf{S}$ & Veg & GSM & TOT & Taxon & & $\mathbf{S} \mid$ Veg & GSM & TOT \\
\hline Dato $/ / 200$ & PORIFERA & 5 & & & & HEMIPTERA & & & & & & DIPTERA & & & & \\
\hline Date://200____ & COELENTERATA & 1 & & & & Belostomatidae* & 3 & & & & & Athericidae & 10 & & & \\
\hline & TURBELLARIA & 3 & & & & Corixidae $^{*}$ & 3 & & & & & Blepharoceridae & 15 & & & \\
\hline 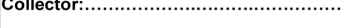 & \begin{tabular}{|l|} 
ANNELIDA \\
\end{tabular} & & & & & Gerridae $^{*}$ & 5 & & & & & Ceratopogonidae & 5 & & & \\
\hline & Oligochaeta & 1 & & & & Hydrometridae $^{*}$ & 6 & & & & & Chironomidae & 2 & & & \\
\hline GridReference: $\quad$ WGS-84|Capedatum & Leeches & 3 & & & & Naucoridae $^{*}$ & 7 & & & & & Culicidae $^{*}$ & 1 & & & \\
\hline 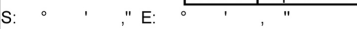 & CRUSTACEA & & & & & Nepidae $^{*}$ & 3 & & & & & Dixidae* & 10 & & & \\
\hline & Amphipoda & 13 & & & & Notonectidae $^{*}$ & 3 & & & & & Empididae & 6 & & & \\
\hline Sitecode:............... & Potamonautidae* & 3 & & & & Pleidae $^{\star}$ & 4 & & & & & Ephydridae & 3 & & & \\
\hline & Atyidae & 8 & & & & Veliidae/M...veliidae* & 5 & & & & & Muscidae & 1 & & & \\
\hline 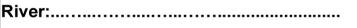 & Palaemonidae & 10 & & & & MEGALOPTERA & & & & & & Psychodidae & 1 & & & \\
\hline & HYDRACARINA & 8 & & & & Corydalidae & 8 & & & & & Simuliidae & 5 & & & \\
\hline 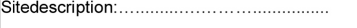 & PLECOPTERA & & & & & Sialidae & 6 & & & & & Syrphidae* & 1 & & & \\
\hline & Notonemouridae & 14 & & & & TRICHOPTERA & & & & & & Tabanidae & 5 & & & \\
\hline WeatherCondition:............... & Perlidae & 12 & & & & Dipseudopsidae & 10 & & & & & Tipulidae & 5 & & & \\
\hline Temp: $\ldots \ldots \ldots \ldots \ldots \ldots . . .{ }^{\circ} \mathrm{C}$ & EPHEMEROPTERA & & & & & Ecnomidae & 8 & & & & & GASTROPODA & & & & \\
\hline Iemp :............ C & Baetidae1sp & 4 & & & & Hydropsychidae1sp & 4 & & & & & Ancylidae & 6 & & & \\
\hline Do. $\mathrm{mg} / \mathrm{l}$ Cond $\mathrm{ms} / \mathrm{m}$ & Baetidae2sp & 6 & & & & Hydropsychidae2sp & 6 & & & & & Bulininae $^{*}$ & 3 & & & \\
\hline DO Cond...............ms & Baetidae $>2$ sp & 12 & & & & Hydropsychidae $>2 \mathrm{sp}$ & 12 & & & & & Hydrobiidae* & 3 & & & \\
\hline Biotopessampled: & Caenidae & 6 & & & & Philopotamidae & 10 & & & & & Lymnaeidae* & $\frac{5}{3}$ & & & \\
\hline Diotopessamilea. & Ephemeridae & 15 & & & & Polycentropodidae & 12 & & & & & Physidae $^{*}$ & 3 & & & \\
\hline SIC $\ldots \ldots \ldots . .$. Time $\ldots \ldots \ldots . . . . m i n u t e s$ & Heptageniidae & 13 & & & & Psychomyiidae/Xiph & 8 & & & & & Planorbinae* & 3 & & & \\
\hline Bedrock................ & Polymitarcyidae & 10 & & & & CalamoceratidaeST & $\frac{11}{11}$ & & & & & PELECYPODA & & & & \\
\hline \begin{tabular}{|ll} 
Aquaticveg'n.......... Dom. & sp $\ldots \ldots \ldots \ldots . . .$. \\
\end{tabular} & Prosopistomatidae & 15 & & & & GlossosomatidaeSW & 11 & & & & & Corbiculidae & 5 & & & \\
\hline 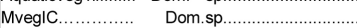 & Teloganodidaeswc & 12 & & & & Hydroptilidae & 6 & & & & & Sphaeriidae & 3 & & & \\
\hline MvegOOC $\ldots \ldots \ldots \ldots \ldots$ Dom.sp $\ldots \ldots \ldots \ldots \ldots \ldots \ldots \ldots \ldots$ & Tricorythidae & 9 & & & & HydrosalpingidaeSW & 15 & & & & & Unionidae & 6 & & & \\
\hline Gravel................... Sand ...................... & ODONATA & & & & & Lepidostomatidae & 10 & & & & & SASSScore & & & & \\
\hline & Caloptervaidaest T & 10 & & & & Leptoceridae & 6 & & & & & No.ofTaxa & & & & \\
\hline Handpicking/Visualobservation.. & Chlorocyphidae & 10 & & & & PetrothrincidaeSWC & 11 & & & & & ASPT & & & & \\
\hline Flow:Low/Medium/High/Flood & Chlorolestidae & 8 & & & & Pisuliidae & 10 & & & & & & & & & \\
\hline Turbidity:Low/Medium/High & Coenagrionidae & 4 & & & & SericostomatidaeSW & 13 & & & & & Samplecollectione & forte & xceedsm & nethod? & \\
\hline Riparianlanduse: & Lestidae & 8 & & & & COLEOPTERA & & & & & & & & & & \\
\hline & Platycnemidae & 10 & & & & Dytiscidae* & 5 & & & & & & & & & \\
\hline Disturbanceintheriver:eg.sandwinning, & Protoneuridae & 8 & & & & Elmidae/Dryopidae* & 8 & & & & & & & & & \\
\hline cattledrinkingpoint,floodsetc. & Aeshnidae & 8 & & & & Gyrinidae $^{\star}$ & 5 & & & & & Otherbiotainclud & gaju & veniles: & & \\
\hline & Corduliidae & 8 & & & & Haliplidae* & 5 & & & & & Jinerolotainciua & igju & venules: & & \\
\hline & Gomphidae & 6 & & & & Helodidae & 12 & & & & & & & & & \\
\hline Observations:eg.smellandcolourof & Libellulidae & $\frac{4}{4}$ & & & & Hydraenidae ${ }^{*}$ & $\frac{14}{8}$ & & & & & Comments: & & & & \\
\hline water, petroleum, deadfish,etc. & LEPIDOPTERA & & & & & Hydrophilidae* & 5 & & & & & & & & & \\
\hline & Pyralidae & 12 & & & & Limnichidae & 10 & & & & & & & & & \\
\hline & & & & & & Psephenidae & 10 & & & & & & & & & \\
\hline
\end{tabular}


Submit or recommend next manuscript to SCIRP and we will provide best service for you:

Accepting pre-submission inquiries through Email, Facebook, LinkedIn, Twitter, etc. A wide selection of journals (inclusive of 9 subjects, more than 200 journals)

Providing 24-hour high-quality service

User-friendly online submission system

Fair and swift peer-review system

Efficient typesetting and proofreading procedure

Display of the result of downloads and visits, as well as the number of cited articles Maximum dissemination of your research work

Submit your manuscript at: http://papersubmission.scirp.org/

Or contact gep@scirp.org 